\title{
Seed dormancy and germination in tree tomato (Solanum betaceum Cav.) and lulo (Solanum quitoense Lam.)
}

\section{Latencia y germinación de semillas de tomate de árbol (Solanum betaceum Cav.) y lulo (Solanum quitoense Lam.)}
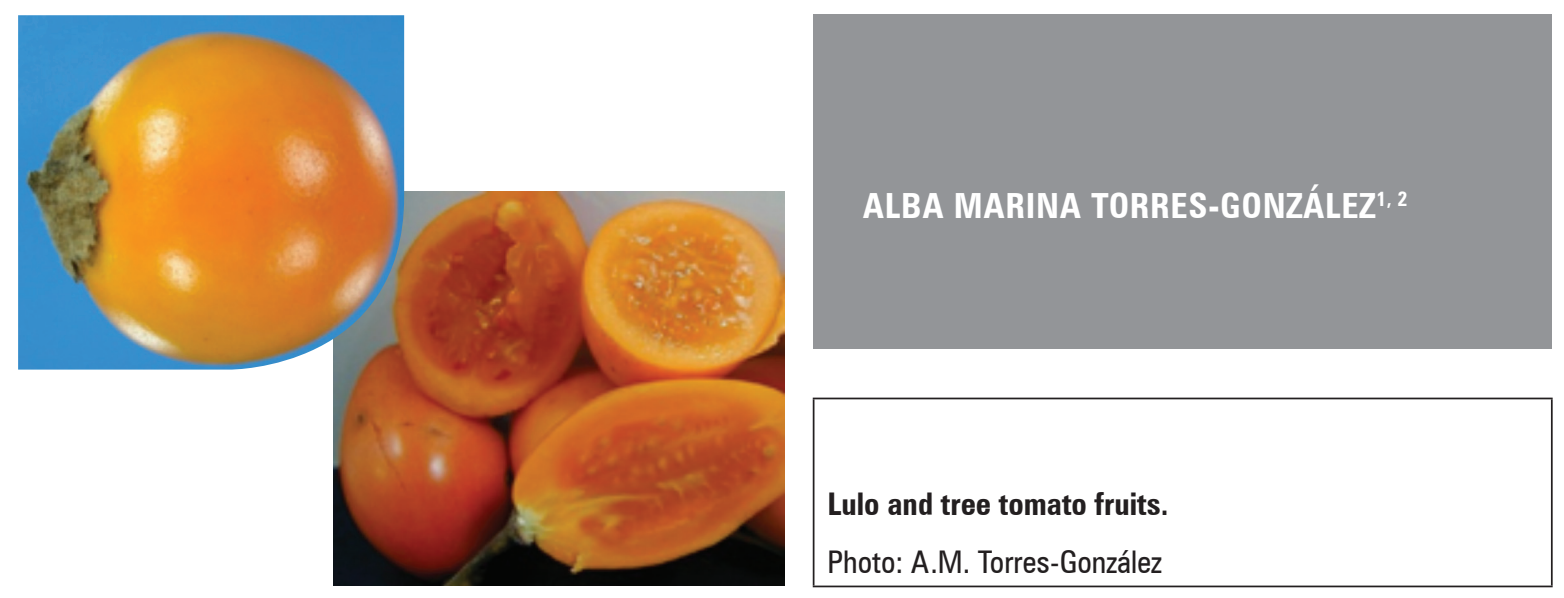

\begin{abstract}
Tree tomato (Solanum betaceum Cav.) and lulo (Solanum quitoense Lam.) fruits enjoy high consumption and commercialization in Colombia. Seed dormancy has been reported for both species, and their propagation depends on seeds. The optimal germination conditions for these species are not well known. Thus, the temperature regimes for the seed germination were based on the mean, minimum and maximum temperatures of the locations where the crops were grown. Germination tests were carried out in four replicates of 50 seeds each on Petri dishes for both crops. Six temperature conditions and four pre-treatments were evaluated to break the seed dormancy for several seed lots. S. betaceum and S. quitoese exhibited shallow seed dormancy, and less dormancy was detected in the commercialized cultivars, such as $S$. betaceum cv. Tamarillo and $S$. quitoense (i.e. common lulo). For both species, the most recently harvested seeds had more germination capacity than the seeds stored for several months at a low seed moisture content $(4 \%)$ and low storage temperature $\left(20^{\circ} \mathrm{C}\right)$. The seed dormancy of $S$. betaceum and $S$. quitoense was broken successfully by applying $\mathrm{GA}_{3}(2,000 \mathrm{mg}$ $\mathrm{L}^{-1}$ ) or alternating temperatures (e.g. $25 / 15^{\circ} \mathrm{C}$ ). However, both treatments at the same time did not provide an additional benefit to promote seed germination. Potassium nitrate (1\%) promoted seed germination in the $S$. betaceum seeds at both constant and alternating temperatures and in the S. quitoense seeds, only when alternating temperatures were applied. The application of $\mathrm{GA}_{3}$ increased the rate of germination more than $\mathrm{KNO}_{3}$ for both species at all temperatures. Using any of these treatments would work well to break seed dormancy in $S$. betaceum and S. quitoense, and the most convenient option could be selected depending upon budget and other resources.
\end{abstract}

\footnotetext{
Additional key words: gibberellic acid; potassium nitrate; seed storage; plant propagation.

1 Universidad del Valle, Faculty of Sciences, Department of Biology, Cali (Colombia). ORCID: Torres-González, A.M.: 0000-0002-3010-2505

2 Corresponding author. alba.torres@correounivalle.edu.co
} 


\section{RESUMEN}

Tomate de árbol (Solanum betaceum Cav.) y lulo (Solanum quitoense Lam.) son frutas altamente consumidas y comercializadas en Colombia. Latencia de semillas ha sido reportada para ambas especies y su propagación se realiza por semillas. Las condiciones óptimas de germinación no son bien conocidas para estas especies. Así, los regímenes de temperatura para la germinación de las semillas fueron usados con base en la temperatura media, mínima y máxima de las localidades donde crecen estos cultivos. Se realizaron pruebas de germinación en cajas de Petri, con seis temperaturas y cuatro pre-tratamientos que fueron probados para romper la latencia de varios lotes de semillas. Los resultados muestran que las dos especies tienen latencia, en menor medida en los cultivares más comercializados, $S$. betaceum cv. Tamarillo y S. quitoense (i.e. cultivar común). Para ambas especies, las semillas recién cosechadas tuvieron mayor promoción de la germinación que las almacenadas por varios meses con bajo contenido de humedad de la semilla $(4 \%)$ y baja temperatura de almacenaiento $\left(20^{\circ} \mathrm{C}\right)$. La latencia de las semillas de S. betaceum y $\mathrm{S}$. quitoense se rompió exitosamente con la aplicación de $\mathrm{GA}_{3}\left(2,000 \mathrm{mg} \mathrm{L}^{-1}\right)$ o temperaturas alternadas (e.g. $\left.25 / 15^{\circ} \mathrm{C}\right)$. Ambos tratamientos al mismo tiempo no tuvieron un beneficio adicional para promover la germinación. $\mathrm{KNO}_{3}(1 \%)$ promovió la germinación de semillas de $S$. betaceum a temperaturas constantes y alternadas, y de semillas de $S$. quitoense solamente a temperaturas alternadas. El pre-tratamiento con $\mathrm{GA}_{3}$ incrementó la velocidad de germinación más que $\mathrm{KNO}_{3}$, para ambas especies y en todas las temperaturas. Se sugiere usar cualquiera de estos tratamientos que funciona bien para romper la latencia de semillas de S. betaceum and S. quitoense, y la opción más conveniente puede ser seleccionada dependiendo del presupuesto y otros recursos.

Palabras clave adicionales: ácido giberélico; nitrato de potasio; almacenamiento de semillas; propagación vegetal.

Received for publication: 04-10-2019 Accepted for publication: 29-11-2019

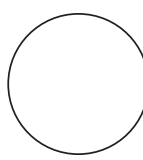

INTRODUCTION

Solanaceae is one of the main plant families of economic importance in Colombia because it provides several food species. Among the edible Solanaceae species, tree tomato (Solanum betaceum Cav. $=$ Cyphomandra betaceum (Cav.) Sendtn.) and lulo (Solanum quitoense Lam.) fruits enjoy high consumption and commercialization in Colombia. Despite being cultivated species, the germplasm of both species studied with COSII molecular markers have a high population structure, which could be the result of low genetic migration between planted populations (Enciso-Rodríguez et al., 2010).

S. betaceum is a domesticated species grown throughout the Andes between 600 and 3,200 m a.s.l. (Bohs, 2015). Moreover, S. betaceum is grown for commercial purposes in New Zealand with the name "Tamarillo", in the Mediterranean area and in Germany (Samuels, 2015). Thus, the name "Tamarillo" has become the standard commercial designation for S. betaceum in Europe, which includes fruits with a dark-purple and red skin that have purple pulp and fruits with a yellow and orange skin with yellow pulp (The Climbing Fig, 2020). However, in the domestic market of
Colombia, the name "Tamarillo" is used exclusively for fruits with a purple skin and pulp.

S. quitoense is cultivated most commonly in Colombia, Ecuador, and Peru at altitudes between 800 and 2,000 m a.s.1. (Bohs, 2015; Gallo et al., 2018). In Colombia, the number of lulo crops has grown because domestic demand has increased (Arias and Rendon, 2015). Two varieties of $S$. quitoense commercially cultivated are $S$. quitoense var. septentrionale with spines and $S$. quitoense var quitoense without spines (Samuels, 2015). S. quitoense is considered one of the species with high gastronomic innovation in the Andean biodiversity (Corzo-Barragan et al., 2016) and is known as the "golden fruit of the Andes" (Ramirez et al., 2018). There is an interspecific hybrid between $S$. quitoense and S. hirtum known as S. quitoense cv. "La Selva", which exhibited greater genetic variability than S. quitoense (Fory et al. 2010).

S. quitoense is propagated by seeds to obtain more vigorous plants, but S. quitoense "La Selva" has to be propagated asexually by cuttings or in vitro micropropagation to conserve the hybrid characteristics (Franco 
et al., 2002). The propagation of these Solanum fruit crops depends mainly on seeds. Micro propagation of hypocotyls, which is an efficient option for massive propagation of $S$. betaceum, starts with seed germination (Criollo et al., 2016). However, seeds frequently exhibit dormancy as an evolutive response of the species to prevent germination until the appropriate time (Shut et al., 2016).

Seed dormancy is found in several cultivated species of Solanum. For instance, seed germination of the common tomato (Solanum lycopersicum L. $=$ Lycopersicon esculentum Mill.) is restricted by seed tissues, such as the embryo by controlling the water potential, the endosperm by controlling cell wall hydrolysis, and the testa by preventing radicle protrusion (Hilhorst, 1997). In tomatoes, cell cycle activity before germination is required, accompanied by nuclear DNA replication, but is blocked in dormant and gibberellin-deficient tomato seeds (Groot et al., 1997). The weed species Solanum nigrum and S. physalifolium exhibit variation in the level of dormancy, enabling populations to escape from weed control or extreme climatic conditions (Taab and Andersson, 2009).

Germination in Solanaceae species is frequently light sensitive. In tobacco (Nicotiana tabacum), there is light dependence during seed germination (Koo et al., 2015), but Solanum elaeagnifolium has similar germination in dark or light conditions (Stanton et al., 2012).

Gibberellic acid promotes germination successfully in potato (Solanum tuberosum) seeds when it is applied at high concentrations of 2,000 $\mathrm{mg} \mathrm{L}^{-1}$ and pre-applied for $24 \mathrm{~h}$ (Spicer and Dionne, 1961). In S. betaceum, alternating temperatures of $28 / 24^{\circ} \mathrm{C}$ for $12 / 12 \mathrm{~h}$ with applications of $\mathrm{GA}_{3}\left(1,000 \mathrm{mg} \mathrm{L}^{-1}\right)$ promoted seed germination, but with an application of $\mathrm{KNO}_{3}(0.2 \%)$, the seed germination of $S$. betaceum and $S$. quitoense decreased (Cárdenas et al., 2004).

Breaking seed dormancy is particularly important for agricultural production because seed germination is the initial phase that ensures the establishment of seedlings and, finally, the crop yield. Thus, this research answered the questions: 1) Is it possible to promote seed germination of $S$. betaceum and $S$. quitoense by applying chemical treatments and incubating at constant or alternate temperatures? 2) Are there differences in seed dormancy between cultivars of $S$. betaceum and S. quitoense?

\section{MATERIALS AND METHODS}

\section{Plant material}

Mature S. betaceum and S. quitoense fruits were purchased from local markets in Cali, Colombia. The storage condition of the seeds are provided in Tab. 1. The seed extraction and conditioning were done following the protocol to extract seeds from fleshy fruits (Torres-González, 2018). All seeds were dehydrated, and some seed lots were stored in cold conditions to prevent loss of viability before testing (Hong and Ellis, 1996). The moisture content test of the seed lots was determined before the germination tests according to the high-constant-temperature-oven method, namely $1 \mathrm{~h}$ drying at $130^{\circ} \mathrm{C}$ (ISTA, 2016). Two samples of $1-2 \mathrm{~g}$ each of the entire seeds were dried in Pyrex Petri dishes $(85 \times 15 \mathrm{~mm})$ in an oven (Thermocenter, SalvisLab, Switzerland) and weighed on an analytical balance (Metler Toledo International Inc., Switzerland) to the nearest $0.01 \mathrm{mg}$ before and after drying. The moisture content was calculated as percentage wet basis (ISTA, 2016).

\section{Germination tests}

Each germination test consisted of four replicates of 50 seeds. No fungicides were added to the substrate to avoid extra chemical factors affecting germination. Scarification for the seeds of these species was not needed.

Constant illumination and alternating temperature incubators were used for the germination tests. The thermoperiod was set for $16 / 8 \mathrm{~h}$ at alternating temperatures. In each case, the first temperature listed for each alternating-temperature regime was provided for $16 \mathrm{~h}$ of each daily cycle; e.g. 15/25 indicates $15^{\circ} \mathrm{C}$ applied for $16 \mathrm{~h} \mathrm{~d}^{-1}$ and $25^{\circ} \mathrm{C}$ applied for $8 \mathrm{~h} \mathrm{~d}^{-1}$. The temperature regimes were based on the mean, minimum and maximum temperatures of the locations where the crops were grown, according to Vargas-Figueroa and Torres-González (2018). The photoperiod was provided for $16 \mathrm{~h}$ per day for both constant and alternating temperatures. In the latter case, the lighting period was synchronous with the longer thermoperiod.

Germination was recorded as radicle protrusion $(\geq$ $2 \mathrm{~mm}$ length). The tests were carried out on $8.5 \mathrm{x}$ $20 \mathrm{~mm}$ Petri dishes with two filter papers (Whatman 
Table 1. Storage time, temperature and moisture of Solanum betaceum and S. quitoense seeds.

\begin{tabular}{|l|c|c|c|c|}
\hline \multicolumn{1}{|c|}{ Cultivar } & Seed lot & Time (months) & Temperature $\left({ }^{\circ} \mathrm{C}\right)$ & Moisture $(\%)$ \\
\hline S. betaceum cv. Tamarillo & A & 7 & 20 & 4.0 \\
\hline S. betaceum cv. Tamarillo & B & 0 & - & 4.0 \\
\hline S. betaceum & C & 7 & 20 & 4.0 \\
\hline S. betaceum & D & 0 & - & 4.0 \\
\hline S. quitoense & A & 2 & 20 & 4.0 \\
\hline S. quitoense cv. La Selva & B & 0 & - & 4.0 \\
\hline
\end{tabular}

Ltd., grade 181) moistened with $4.5 \mathrm{~mL}$ of deionized water. One Petri dish was used for each replicate, and four dishes were placed in a loosely folded plastic bag. The duration of the test was $21 \mathrm{~d}$. The germination tests were checked three times a week to record the progress of germination during tests.

Several chemical pre-treatments were applied for $24 \mathrm{~h}$ at $20^{\circ} \mathrm{C}$ before beginning germination tests; $30 \mathrm{~mL}$ of solution was used to soak 100-200 seeds.

\section{Experiment design}

For each species, the seed lots included the varieties cultivated and commercialized in Colombia (Tab. 1). The temperature regimes were 1) constant temperature, $15^{\circ} \mathrm{C}$; 2) constant temperature, $25^{\circ} \mathrm{C}$; 3) alternating temperatures, $15 / 25^{\circ} \mathrm{C}$; 4) alternating temperatures, $\left.25 / 15^{\circ} \mathrm{C}, 5\right)$ alternating temperatures, $20 / 30^{\circ} \mathrm{C}$; and 6) alternating temperatures $20 / 35^{\circ} \mathrm{C}$. The controls and treatments were: 1) dry seeds, as dry control; 2) deionized water, as pre-applied control; 3) gibberellic acid $\left(\mathrm{GA}_{3}\right), 2,000 \mathrm{mg} \mathrm{L}^{-1}$; and 4) potassium nitrate $\left(\mathrm{KNO}_{3}\right), 1 \%$.

The experiments had a factorial design that differed among the species. Thus, for $\mathrm{S}$. betaceum the factorial was $4 \times 6 \times 4$, and, for S. quitoense, it was $2 \times 6 \times 4$, indicating the number of seed lots, temperature regimes and pre-treatments applied, respectively.

\section{Statistical analysis}

The rate of germination was calculated with the formula used by Torres-González (2018): $\mathrm{R}=\sum$ (n/ $\left(d^{*} n\right)$ ), where $n$ is the number of seeds germinated on day $d$, and, $d$ is the number of days from the beginning of the germination test.

For normality of variances for the analysis of variance, the germination percent was transformed to angles using the arcsine function for the formula: angles (radians) $=\operatorname{Arcsin} \sqrt{ }(\%$ germination $/ 100)$. The angles were transformed from radians to degrees. The analysis of variance (ANOVA) was used to compare the variation between factors. An analysis of normality and homogeneity of variance of the transformed data was performed. The SAS software was used for these analyses (SAS, 2020). The $\alpha$ level to determine the significance in the $\mathrm{F}$ test was 0.05 . When no interaction between factors was found, $a$ posteriori Tukey test was applied $(P \leq 0.05)$.

\section{RESULTS}

\section{Solanum betaceum Cav. (tree tomato)}

Depending upon the treatment combination, the germination ranged from 13 to 99\% (Fig. 1, $P<0.05$ ). Seed lots A and B of cultivar Tamarillo had higher germination than the common cultivar (lots $\mathrm{C}$ and $\mathrm{D}$ ). In the majority of treatments for both cultivars, the recently extracted seeds (lots $\mathrm{B}$ and $\mathrm{D}$ ) germinated better than the seeds stored for seven months (lots A and $\mathrm{C}$ ). The alternating temperatures $25 / 15^{\circ} \mathrm{C}$ gave the greatest germination for all treatments over the other temperature regimes. The interaction between the effect of alternating temperature $\left(25 / 15^{\circ} \mathrm{C}\right)$ and application of either gibberellic acid or potassium nitrate for seed lot B showed that the two different pre-treatments not only had similar effects but also had a similar effect to that of temperature alternations, while there were no additive effects from pretreatment and alternation (Fig. 2).

In consequence, high germination was obtained with gibberellic acid and potassium nitrate pre-treatment at constant temperature (97 and 95\%, respectively) or in the water control at an alternating temperature of $25 / 15^{\circ} \mathrm{C}(95 \%)$. The lowest germination occurred 
for dry seeds at a constant temperature of $15^{\circ} \mathrm{C}$ for all seed lots (13-40\%), demonstrating that soaking in water at this temperature was beneficial $(38-80 \%)$, (Fig. 1).
The rate of germination was affected by all factors with significant interactions between them $(P \leq 0.05)$. The highest rate of germination was at 25 and $25 / 15^{\circ} \mathrm{C}$ with pre-treatment in gibberellic acid

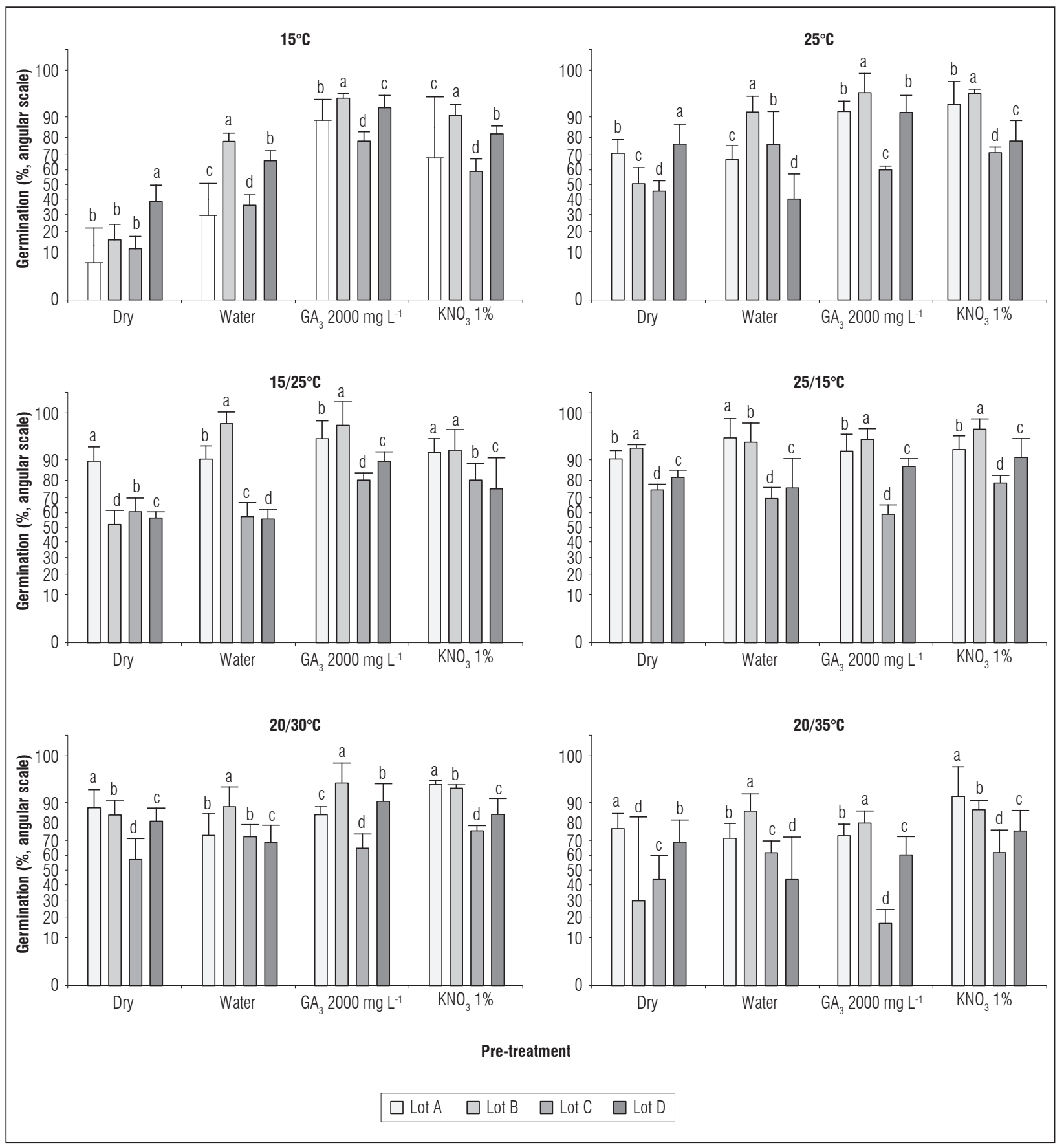

Figure 1. Effect of constant or alternating temperature and several pre-treatments on the germination of four seed lots of Solanum betaceum Cav. Lot A: cv. Tamarillo, 7 months in storage, lot B: cv. Tamarillo, 0 months in storage, lot C: common tree tomato, 7 months in storage, lot $D$ : common tree tomato, 0 months in storage. Means with different letters indicate significant statistical difference within each pre-treatment according to the Tukey test $(P \leq 0.05 ; n=4)$. The vertical bars indicate \pm standard error. 
(Fig. 3). In these regimes, lots $\mathrm{A}, \mathrm{B}$ and $\mathrm{D}$ showed similar rapid rates of germination, with lot $C$ being appreciably slower.

\section{Solanum quitoense (lulo)}

The germination was affected by all factors, their second-order interaction and by the first-order interaction between temperature and pre-treatment $(P \leq 0.05)$. Generally, lot A (i.e. common cultivar) had greater germination in the tested temperatures and treatments than lot B (cv. La Selva), (Fig. 4). The alternating temperature regime $25 / 15^{\circ} \mathrm{C}$ gave a higher germination for all treatments, even for the dry and water controls. However, gibberellic acid promoted
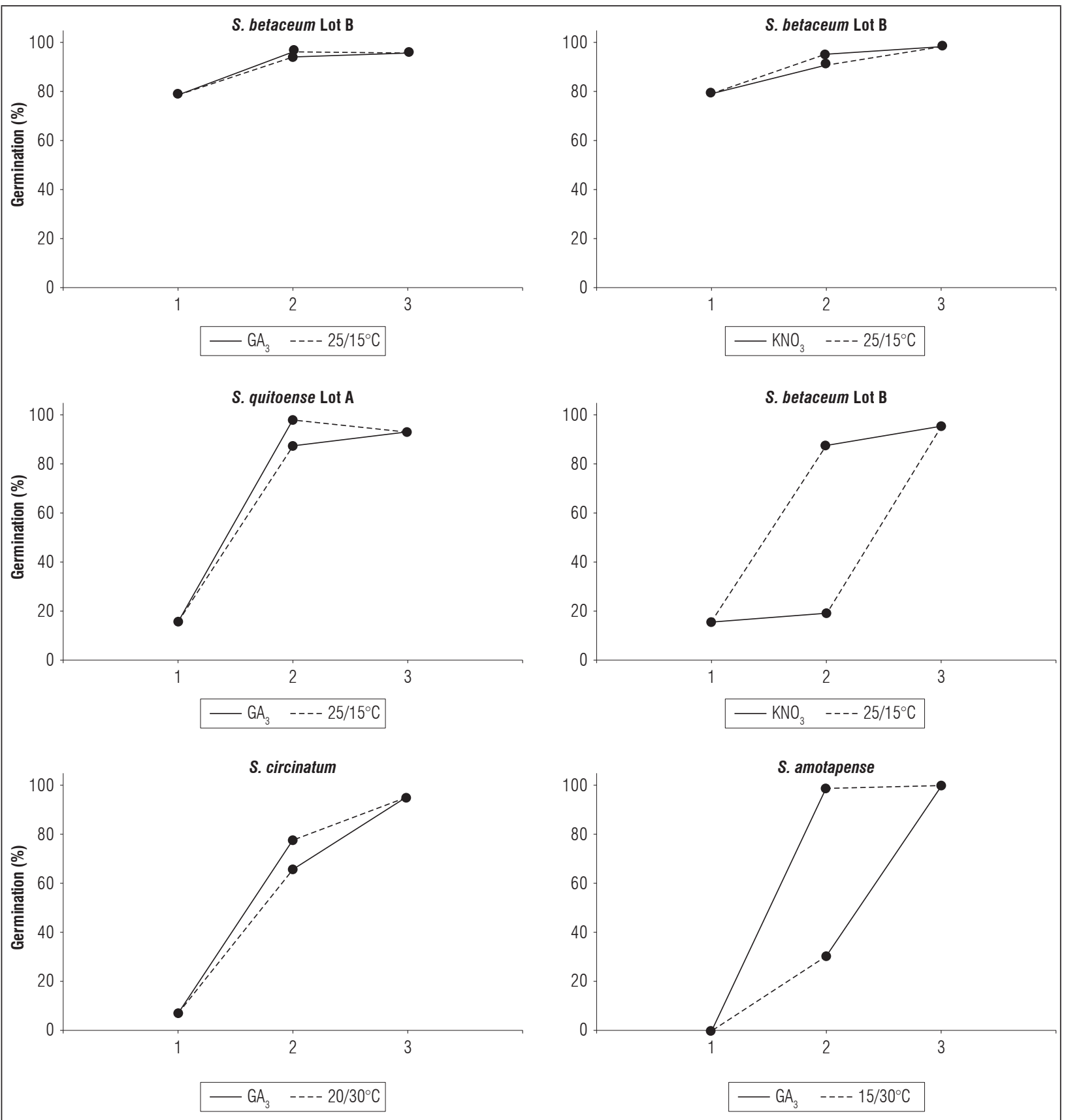

Figure 2. Interaction between factors promoting germination of Solanum betaceum Cav. Lot B (control: $15^{\circ} \mathbf{C}$, water) and $S$. quitoense Lam. Lot A (control: $\mathbf{1 5}^{\circ} \mathrm{C}$, water). 0: no factors applied, 1: one factor applied, 2: two factors applied. 
germination substantially at temperatures with less promotion of seed germination (e.g. $91-100 \%$ at $\left.25^{\circ} \mathrm{C}\right)$. The interaction between gibberellic acid and alternating temperature $\left(25 / 15^{\circ} \mathrm{C}\right)$ was, therefore, negative because either factor promoted close to full germination (Fig. 2). In contrast, the effects of alternating temperature $\left(25 / 15^{\circ} \mathrm{C}\right)$ and pre-treatment with potassium nitrate were additives (Fig. 2).

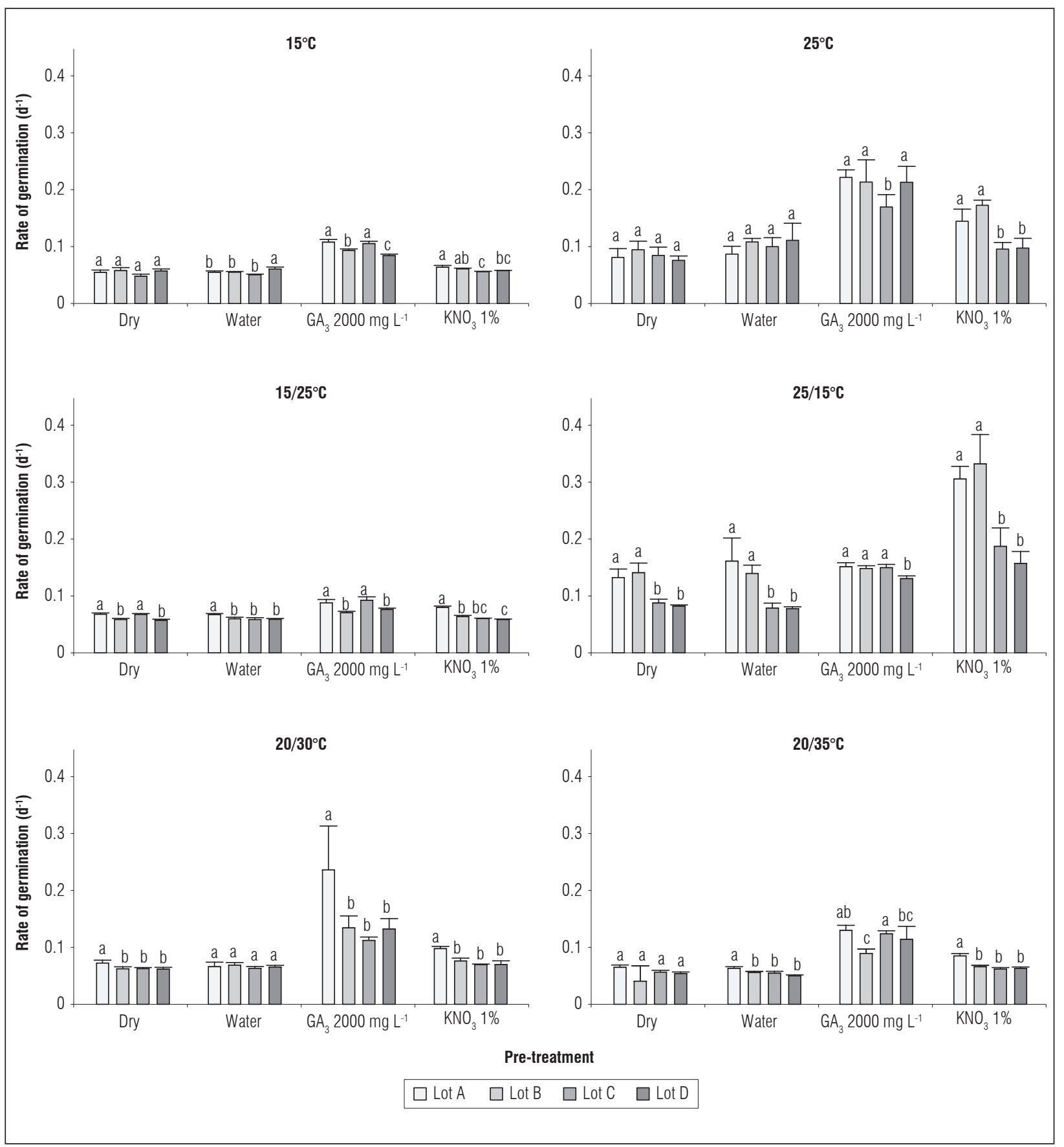

Figure 3. Effect of constant or alternating temperature and pre-treatment on the rate of germination of four seed lots of Solanum betaceum Cav. Lot A: cv. Tamarillo, 7 months in storage, lot B: cv. Tamarillo, 0 months in storage, lot C: common tree tomato, 7 months in storage, lot $D$ : common tree tomato, 0 months in storage. Means with different letters indicate significant statistical difference within each pre-treatment according to the Tukey test $(P \leq 0.05 ; n=4)$. The vertical bars indicate \pm standard error. 
The rate of germination was significantly affected by all factors and most of their interactions $(P \leq 0.05)$. The highest rate of germination was found for the common variety (lot A) at $25 / 15^{\circ} \mathrm{C}(16 / 8 \mathrm{~h})$ with pre-treatment in $\mathrm{GA}_{3}$ (Fig. 5) In all temperature regimes, pre-treatment with $\mathrm{GA}_{3}$ provided the most rapid germination.

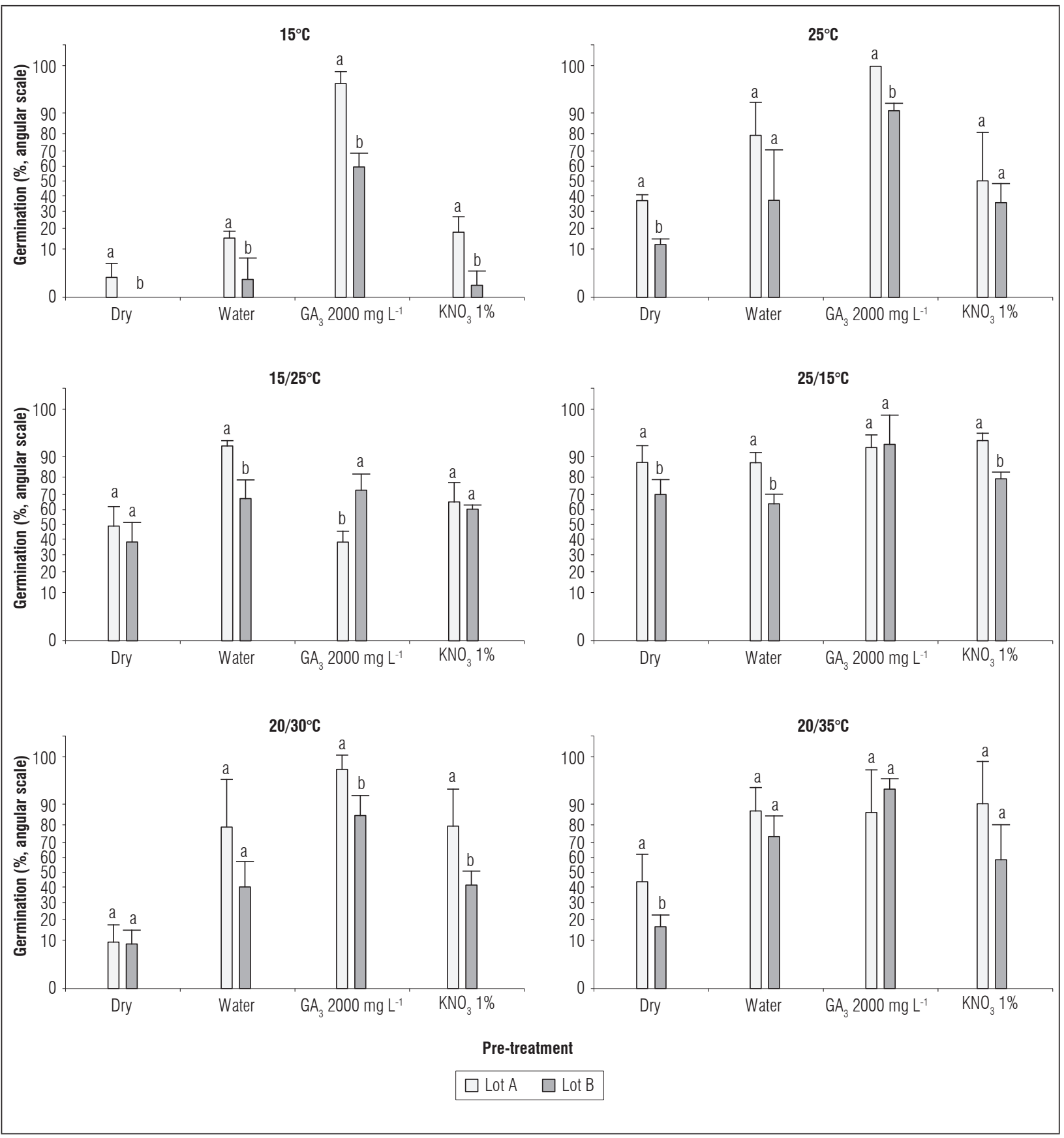

Figure 4. Effect of constant or alternating temperature and several pre-treatments on the germination of two seed lots of Solanum quitoense Lam. (21 d duration), Lot A: common lulo, 2 months in storage, Lot B: cv. La Selva, 0 months in storage. Means with different letters indicate significant statistical difference within each pre-treatment according to the Tukey test $(P \leq 0.05 ; n=4)$. The vertical bars indicate \pm standard error. 


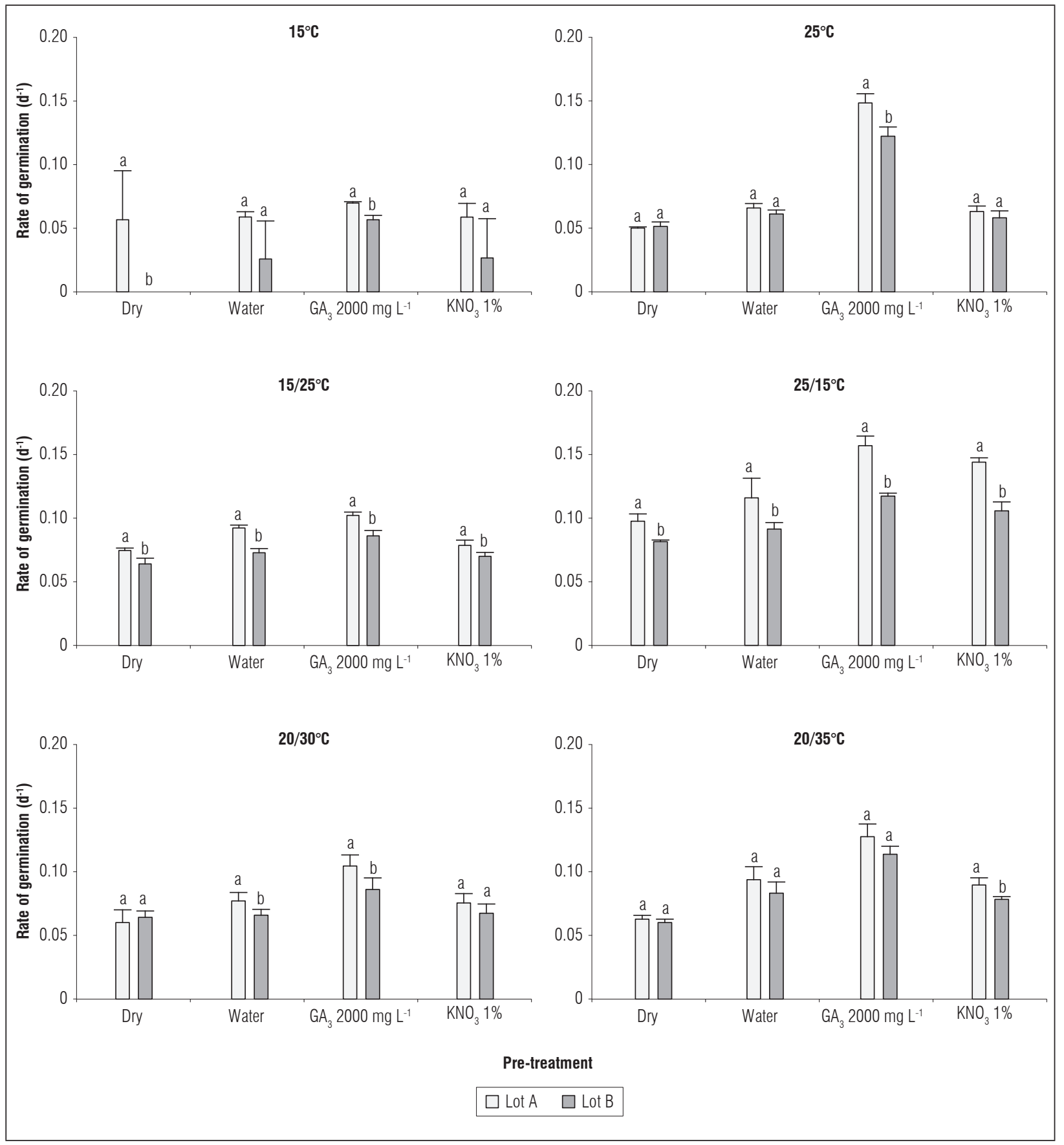

Figure 5. Effect of constant or alternating temperature and several pre-treatments on the rate of germination of two seed lots of Solanum quitoense Lam. Lot A: common lulo, 2 months in storage, Lot B: cv. La Selva, 0 months in storage. Means with different letters indicate significant statistical difference within each pre-treatment according to the Tukey test $(P \leq 0.05 ; n=4)$. The vertical bars indicate \pm standard error.

\section{DISCUSSION}

The germination varied considerably among the seed lots, the different temperature regimes, and the different pre-treatments in both species of Solanum. The seeds of $S$. betaceum and S. quitoese were dormant, and less dormancy was found in the cultivars Tamarillo of S. betaceum and common lulo (S. quitoense). 
Dormancy was broken successfully for the $S$. betaceum and S. quitoense seeds. In both species, the best temperature to promote seed germination was the alternating temperature $\left(25 / 15^{\circ} \mathrm{C}\right)$ for all treatments and seed lots. At constant temperatures, the promotion of germination was lower for the dry and water controls, meanwhile, gibberellic acid had a substantial, positive effect. However, the action of alternate temperature and gibberellic acid at the same time did not provide additional benefits to germination. Also, for both species, the gibberellic acid positively affected the rate of germination at all temperatures, particularly at $25 / 15$ and $25^{\circ} \mathrm{C}$.

One way to release seed dormancy in other Solanum species is alternating temperatures; e.g. S. elaeagnifolium (Trione and Cony, 1990), and S. physalifolium (Monte and Tarquis, 1997) with amplitudes exceeding $5{ }^{\circ} \mathrm{C}$. Alternating temperatures occur in the natural tropical Andean ecosystem where $S$. betaceum and S. quitoense crops are cultivated. Thus, choosing the minimum, mean and maximum temperatures of the Andean ecosystem for the germination test (VargasFigueroa and Torres-González, 2018) was a clue to obtaining successful germination for this species.

On the other hand, potassium nitrate $(1 \%)$ promoted seed germination of the $S$. betaceum seeds at both constant and alternating temperatures. However, potassium nitrate promoted seed germination in $S$. quitoense only when the alternating temperature was applied, and, at the constant temperature, there was no promotion by potassium nitrate at all. These results agree with Yogeesha et al. (2006), who broke seed dormancy in two cultivars of Solanum melongena L. with gibberellic acid; however, potassium nitrate only improved germination to some extent. In this sense, these results agree with the results of Wei et al. (2010), who promoted germination in S. lycopersicum with gibberellic acid in higher percent (>98\%) than with potassium nitrate ( $>70 \%)$. Also, the application of gibberellic acid to the S. lycopersicum seeds produces seedlings with higher vigor (Balaguera-López et al., 2009).

These results confirm the study of Cárdenas et al. (2004) on S. betaceum and S. quitoense, where dormancy was broken by an alternating temperature regime of $28 / 24{ }^{\circ} \mathrm{C}(12 / 12 \mathrm{~h})$. They found a similar benefit for these species from $\mathrm{GA}_{3}\left(1,000 \mathrm{mg} \mathrm{L}^{-1}\right)$, but, in the present study, a slight increase in the germination was obtained for $S$. betaceum with $\mathrm{GA}_{3}$ at a higher concentration $\left(2,000 \mathrm{mg} \mathrm{L}^{-1}\right)$. However, these results contradict their results of declining germination with the application of $\mathrm{KNO}_{3}(2 \%)$, perhaps because a lower concentration was used (1\%). The positive response of the Solanum species studied here, and in other research, to gibberellins and nitrate in breaking seed dormancy shows the presence of a shallow seed dormancy, which is a result of gene expression (Finch-Savage and Footitt, 2017).

There was a difference in the promotion of germination between the cultivars of both species. S. betaceum cv. Tamarillo achieved higher germination than the common cultivar. However, the rate of germination was very similar for both cultivars. On the other hand, the common cultivar of $S$. quitoense had higher germination and rate of germination than $\mathrm{cv}$. La Selva. The most commercial cultivars of these fruits seem to provide the highest germination results. This is because S. quitoense cv. La Selva is a cross between the cultivated species and a wild species (Fory, 2010) and an inter-specific hybrid that is much less cultivated. On another hand, S. betaceum cv. Tamarillo is a very high-yielding variety that produces large bright red fruits, and, of all varieties of this crop, it is one of the most rewarding and cultivated (The Climbing Fig, 2020).

\section{CONCLUSIONS}

S. betaceum and S. quitoese exhibited shallow seed dormancy, and less dormancy was found in the more commercialized cultivars, such as $S$. betaceum cv. Tamarillo and S. quitoense (i.e. common cultivar). For both species, the most recently harvested seeds had more promotion of germination than the seeds stored for several months at the low seed moisture content $(4 \%)$ and low storage temperature $\left(20^{\circ} \mathrm{C}\right)$. Despite this, the storage conditions did not have a detriment on the seed germination of the tomate tree and lulo.

The seed dormancy of $S$. betaceum and S. quitoense was broken successfully by applying gibberellic acid $\left(2,000 \mathrm{mg} \mathrm{L}^{-1}\right)$ or alternating temperatures, particularly $25 / 15^{\circ} \mathrm{C}$. The application of one or another treatment was enough because both treatments at the same time did not have an additional benefit for promoting seed germination. Meanwhile, the application of gibberellic acid increased the rate of germination more than potassium nitrate, at all temperatures. However, potassium nitrate $(1 \%)$ promoted the seed germination of $S$. betaceum seeds at both constant and alternating temperatures and of 
S. quitoense seeds only when the alternating temperature was applied.

The suggestion is for farmers to apply any of these treatments that work well at breaking seed dormancy in S. betaceum and S. quitoense; the most convenient option could be selected depending upon budget and other resources.

\section{ACKNOWLEDGMENTS}

The author thanks COLCIENCIAS (Colombian Administrative Department of Science, Technology and Innovation) for study abroad Ph.D. grant and Dr. Richard Ellis and Dr. Tran Hong, University of Reading (UK), for academic guidance.

Conflict of interest. The manuscript was prepared by the author, who declares that she has no conflicts of interest that put at risk the validity of the results presented here.

\section{BIBLIOGRAFHIC REFERENCES}

Arias, F.J. and S. Rendón. 2015. Inteligencia de mercados para la cadena del lulo (Solanum quitoense). J. Agric. An. Sci. 3(2), 38-47.

Balaguera-López, H.E., Y.A. Deaquiz, and J.G. Alvarez-Herrera. 2009. Plántulas de tomate (Solanum lycopersicum L.) provenientes de semillas embebidas en diferentes soluciones de giberelinas $\left(\mathrm{GA}_{3}\right)$. Agron. Colomb. 27(1), 57-64.

Bohs, L.A. 2015. Solanaceae. In: Hammel, B.E., M.H. Grayum, C. Herrera, and N. Zamora (eds.). Manual de plantas de Costa Rica. Monogr. Syst. Bot. Missouri Bot. Gard. 8(131), 205-336.

Cárdenas, W., M.L. Zuluaga, and M. Lobo. 2004. Latencia en semillas de lulo (Solanum quitoense Lam.) y tomate de árbol (Cyphomandra betacea (Solanum betaceum) Cav. Sendt) como aspecto básico para la conservación y el monitoreo de viabilidad de las colecciones. PGR Newsl. 139, 31-41.

Corzo-Barragan, D., M. Torres, R. Pacheco, L. Moreno-Chacón, S. Castañeda-Garzón, M.S. Hernández, Y. Quiñones, and N. Chavarro-Rodríguez. 2016. Biodiversidd altoandina al plato de todos: apuesta para fortalecer la industria agroalimentaria en Colombia. Agron. Colomb. 34(Suppl. 1), 1186-1189.

Criollo, H.E., K. Insuasti, and W. Delgado. 2016. Regeneración in vitro de plántulas de tomate de árbol (Solanum betaceum (Cav.) Sendt.). Rev. Colomb. Cienc. Hortic. 10(2), 252-261. Doi: 10.17584/rcch.2016v10i2.5750
Enciso-Rodríguez, F., R. Martínez, M. Lobo, and L.S. Barrero. 2010. Genetic variation in the Solanaceae fruit bearing species lulo and tree tomato revealed by conserved ortholog (COSII) markers. Genet. Mol. Biol. 33(2), 271-278. Doi: 10.1590/S1415-47572010005000016

Finch-Savage, W.E. and S. Footitt. 2017 Seed dormancy cycling and the regulation of dormancy mechanisms to time germination in variable field environments. J. Exp. Bot. 68(4), 843-856. Doi: 10.1093/jxb/erw477

Fory, P.A., I. Sánchez, A. Bohórquez, H. Ramírez, C.I. Medina, and M. Lobo. 2010. Genetic variability of the Colombian collection of Lulo (Solanum quitoense Lam.) and related species of section Lasiocarpa. Rev. Fac. Nal. Agr. Medellín 63(2), 5465-5476.

Franco, G., J. Bernal, M.J. Giraldo, P.J. Tamayo, O. Castaño, A. Tamayo, J.L. Gallego, M. Botero, J.E. Rodríguez, N.J. Guevara, J.E. Morales, M. Londoño, G. Ríos, J.L. Rodríguez, J.H. Cardona, J. Zuleta, J. Castaño, and J.C. Ramírez. 2002. El cultivo del lulo. Manual Técnico. Asociación Hortifrutícola de Colombia; Fondo Nacional de Fomento Hortifrutícola; Corporación Colombiana de Investigación Agropecuaria, Manizales, Colombia.

Gallo, Y., L.F. Toro, H. Jaramillo, P.A. Gutiérrez, and M. Marín. 2018. Identificación y caracterización molecular del genoma completo de tres virus en cultivos de lulo (Solanum quitoense) de Antioquia (Colombia). Rev. Colomb. Cienc. Hortic. 12(2), 281-292. Doi: 10.17584/ rcch.2018v12i2.7692

Groot, S.P.C., R. De Castro, Y. Liu, and R.J. Bino. 1997. Cell cycle analysis in dormant and germinating tomato seeds. pp. 395-402. In: Ellis, R.H., M. Black, A.J. Murdoch, and T.D. Hong (eds.). Basic and applied aspects of seed biology. Kluwer Academic Publishers, Dordrecht, The Netherlands. Doi: 10.1007/978-94-011-5716-2_43

Hilhorst, H.W.M. 1997. Primary dormancy in tomato. Further studies with the sitiens mutants. pp. 191201. In: Ellis, R.H., M. Black, A.J. Murdoch, and T.D. Hong (eds.). Basic and applied aspects of seed biology. Kluwer Academic Publishers, Dordrecht, The Netherlands. Doi: 10.1007/978-94-011-5716-2_22

Hong, T.D. and R.H. Ellis. 1996. A protocol to determine seed storage behaviour. IPGRI Technical Bulletin No. 1. International Plant Genetic Resources Institute, Rome.

ISTA, International Seed Testing Association. 2016. International rules for seed testing. Bassersdorf, Switzerland.

Koo, H.J., S.M. Park, K.P. Kim, M.C. Suh, M.O. Lee, S.K. Lee, X. Xinli, and C.B. Hong. 2015. Small heat shock proteins can release light dependence of tobacco seed during germination. Plant Physiol. 167(3), 1030-1038. Doi: 10.1104/pp.114.252841

Monte, J.P.D. and A.M. Tarquis. 1997. The role of temperature in the seed germination of two species of the Solanum nigrum complex. J. Exp. Bot. 48(317), $2087-$ 2093. Doi: $10.1093 / j x b / 48.12 .2087$ 
Ramirez, F., J. Kallarackalb, and T.L. Davenport. 2018. Lulo (Solanum quitoense Lam.) reproductive physiology: a review. Sci. Hort. 238: 163-176. Doi: 10.1016/j. scienta.2018.04.046

Samuels, J. 2015. Biodiversity of food species of the Solanaceae family: a preliminary taxonomic inventory of Subfamily Solanoideae. Resources 4, 277-322. Doi: 10.3390/resources4020277

SAS, Institute Inc. 2020. SAS/STAT ${ }^{\circledR} 9.1$ user's guide. Cary, NC.

Shut, K., X.D., Liu, Q., Xie, and Z.H. He. 2016. Two faces of one seed: hormonal regulation of dormancy and germination. Mol. Plant 9, 34-45. Doi: 10.1016/j. molp.2015.08.010

Spicer, P.B. and L.A. Dionne. 1961. Use of gibberellin to hasten germination of Solanum seed. Nature 189, $327-$ 328. Doi: $10.1038 / 189327 a 0$

Stanton, R., H. Wu, and D. Lemerle. 2012. Factor affecting silverleaf nightshade (Solanum elaeagnifolium) germination. Weed Sci. 60(1), 42-47. Doi: 10.1614/ WS-D-11-00105.1

Taab, A. and L. Andersson. 2009. Primary dormancy and seedling emergence of black nightshade (Solanum nigrum) and hairy nightshade (Solanum physalifolium). Weed Sci. 57(5), 526-532. Doi: 10.1614/WS-09-050.1
The Climbing Fig. 2019. Cyphomandra colombian tamarillo seeds https://theclimbingfig.com.au/products/ cyphomandra-colombian-tamarillo-seeds, consulted: December, 2019.

Torres-González, A.M. 2018. Seed dormancy and germination of two cultivated species of Passifloraceae. Bol. Cient. Mus. Hist. Nat. 22(1), 15-27.

Trione, S.O. and M.A. Cony. 1990. Thermoperiodism and other physiological traits of Solanum elaeagnifolium seeds in relation to germination. Seed. Sci. Technol. 18,525 .

Vargas-Figueroa, J.A. and A.M. Torres-González. 2018. Germination and seed conservation of a pioneer species, Tecoma stans (Bignoniaceae), from tropical dry forest of Colombia. Rev. Biol. Trop. 66(2), 918-936. Doi: 10.15517/rbt.v66i2.33423

Wei, S., C. Zhang, X. Chen, X. Li, B. Sui, H. Huang, H. Cui, Y. Liu, M. Zhang, and F. Guo. 2010. Rapid and effective methods for breaking seed dormancy in buffalobur (Solanum rostratum). Weed Sci. 58(2), 141-146. Doi: 10.1614/WS-D-09-00005.1

Yogeesha, H.S., K.K. Upreti, K. Padmini, K. Bhanuprakash, and G.S.R. Murti. 2006. Mechanism of seed dormancy in eggplant (Solanum melongena L.). Seed Sci. Technol. 34, 319-325. Doi: 10.15258/sst.2006.34.2.07 